\title{
Spylidone, a Novel Inhibitor of Lipid Droplet Accumulation in Mouse Macrophages Produced by Phoma sp. FKI-1840
}

\author{
Nobuhiro Koyama, Tomoko Nagahiro, Yuichi Yamaguchi, Taichi Ohshiro, \\ Rokuro Masuma, Hiroshi Tomoda, Satoshi Ōmura
}

Received: March 14, 2005 / Accepted: May 9, 2005

(C) Japan Antibiotics Research Association

\begin{abstract}
During our screening for microbial inhibitors of lipid droplet accumulation in macrophages, a new compound designated spylidone was isolated along with two structurally related known compounds, PF1052 and vermisporin, from the fermentation broth of Phoma sp. FKI-1840 by solvent extraction, silica gel column chromatography, ODS column chromatography and preparative HPLC. From the structure elucidation, spylidone has a spiro ring containing 2,4-pyrrolidinedione. Among the three compounds, only spylidone was found to inhibit lipid droplet accumulation in macrophages at $10 \sim 50 \mu \mathrm{M}$ without any cytotoxic effect.
\end{abstract}

Keywords spylidone, atherosclerosis, macrophage, lipid droplet accumulation, spiro ring, pyrrolidinedione

\section{Introduction}

In the early stage of atherosclerogenesis, macrophages penetrate into the intima, efficiently take up modified low density lipoprotein, store cholesterol and fatty acid as a respective form of cholesteryl ester (CE) and triacylglycerol (TG) in the cytosolic lipid droplets, and are converted into foam cells, leading to the development of atherosclerosis in the arterial wall. Therefore, inhibition of lipid droplet accumulation in macrophages would be expected to retard the progression of atherosclerosis [1 4]. In the course of our screening program for microbial inhibitors of lipid droplet accumulation in macrophages [5 8], three structurally related compounds were isolated

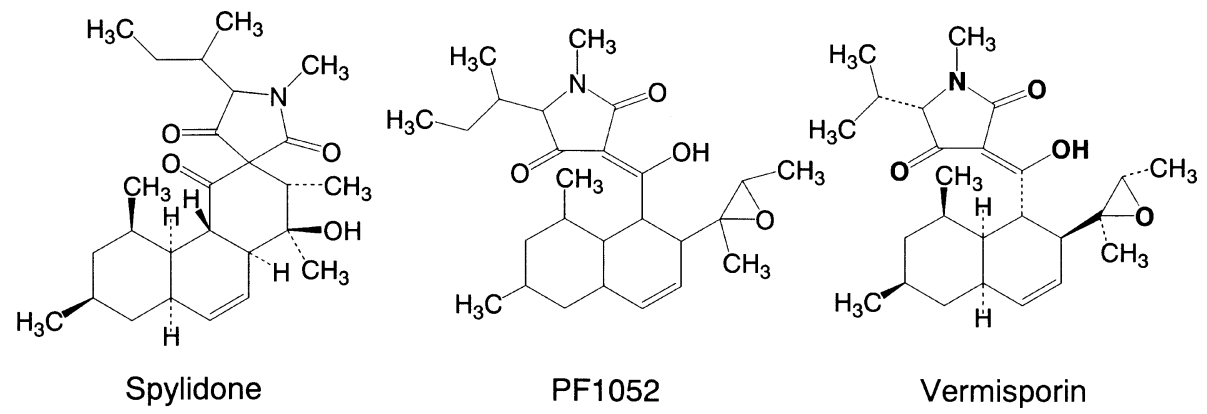

Fig. 1 Structures of spylidone, PF1052 and vermisporin.

H. Tomoda (Corresponding author): School of Pharmaceutical Sciences, Kitasato University, 5-9-1 Shirokane, Minato-ku, Tokyo 108-8641, Japan, E-mail: tomoda@lisci.kitasato-u.ac.jp

N. Koyama, T. Nagahiro, T. Ohshiro, R. Masuma, S. Ōmura: Kitasato Institute for Life Sciences and Graduate School of
Infection Control Sciences, Kitasato University, 5-9-1 Shirokane, Minato-ku, Tokyo 108-8641, Japan

Y. Yamaguchi, H. Tomoda, S. Ōmura: The Kitasato Institute, 59-1 Shirokane, Minato-ku, Tokyo 108-8642, Japan 
from the culture broth of a soil-isolated fungus FKI-1840. One was found to be a new inhibitor designated spylidone, but the others were identified as PF1052 [9] and vermisporin [10] previously reported as antibiotics (Fig. 1). In this paper we describe the taxonomy of the producing strain and fermentation, isolation, structure elucidation, and biological properties of spylidone.

\section{Materials and Methods}

\section{General Experimental Procedures}

Fungal strain FKI-1840 was originally isolated from a soil sample collected at Miyakojima Island, Okinawa Prefecture, Japan. This strain was used for production of spylidone, PF1052 and vermisporin. Kieselgel 60 (E. Merck) and SSC-ODS-7515-12 (Senshu Sci.) were used for silica gel and octadecyl silyl (ODS) column chromatography, respectively. HPLC was carried out using L-6200 system (Hitachi). For determination of the amounts of spylidone, PF1052 and vermisporin in culture broths, the samples (ethyl acetate extracts) dissolved in methanol were analyzed by HP1100 system (Hewlett Packard) under the following conditions: column, Symmetry $(2.1 \times 150 \mathrm{~mm}$, Waters); flow rate, $0.2 \mathrm{ml} /$ minute; mobile phase, a 20 minute linear gradient from $60 \% \mathrm{CH}_{3} \mathrm{CN}$ to $100 \% \mathrm{CH}_{3} \mathrm{CN}$ containing $0.05 \% \mathrm{H}_{3} \mathrm{PO}_{4}$; detection, $\mathrm{UV}$ at $210 \mathrm{~nm}$. Under these conditions, spylidone, PF1052 and vermisporin were eluted with retention times of 10.2, 16.8 and 14.9 minutes, respectively.

UV spectra were recorded on a spectrophotometer (DU640, Beckman). IR spectra were recorded on a Fourier transform infrared spectrometer (FT-710, Horiba). Optical rotations were measured with a digital polarimeter (DIP370, JASCO). FAB-MS spectra were recorded on a mass spectrometer (JMS-DX300, JEOL), and HRFAB-MS spectra were recorded on a mass spectrometer (JMSAX505 HA, JEOL). The various NMR spectra were measured with a spectrometer (XL-400, Varian).

\section{Taxonomic Studies of the Producing Fungus}

Taxonomic studies were carried out by established methods [11]. Oatmeal agar (OA) and malt extract agar (MEA) plates $[20 \mathrm{ml}$ medium per $90 \mathrm{~mm}$ plastic Petri dish (Kanto Chemical)] were prepared. The fungus was inoculated as a mycelial disk in the center of the plates, which were incubated under darkness at $22^{\circ} \mathrm{C}$ for one week. After that, the plates were placed in a biophotochamber (LX-2200, Taitec) under near-ultraviolet exposure with the black light blue lamps (FL40S BLB, Toshiba) for 13 hours, then under darkness for 11 hours. Morphological characteristics were observed under a light microscope (Vanox-S AH-2, Olympus). Color names and hue numbers were determined according to the Color Harmony Manual [12]. For light microscope observation, the pycnidia were fixed by immersion in $8 \%$ formaldehyde, frozen in TissueTek O.T.C compound (Sakura), and stored at $-20^{\circ} \mathrm{C}$ until sectioning [13].

\section{Assay for Lipid Droplet Formation in Macrophages}

Assay for lipid droplet formation in mouse macrophages was carried out according to the method described previously [14]. In brief, primary mouse peritoneal macrophages $\left(2 \times 10^{6} \mathrm{cell} / \mathrm{s} / \mathrm{ml}\right)$ in GIT medium (Nippon Seiyaku) were added to each well of a 96-well plastic microplate (Corning) and incubated in a humidified $\mathrm{CO}_{2}$ $(5 \% \mathrm{v} / \mathrm{v})$ atmosphere at $37^{\circ} \mathrm{C}$ for 2 hours. The medium was then replaced immediately with $0.125 \mathrm{ml}$ of medium A [Dulbecco's modified Eagle medium (Nissui Seiyaku) containing 8\% (v/v) lipoprotein-deficient serum [15], penicillin (100 units/ml) and streptomycin $(100 \mu \mathrm{g} / \mathrm{ml})]$. After another 2-hour preincubation, $1.25 \mu \mathrm{l}$ of a sample (methanol solution) and $5.0 \mu \mathrm{l}$ of liposomes (phosphatidylcholine $1.0 \mu \mathrm{mol}$, phosphatidylserine 1.0 $\mu \mathrm{mol}$, dicetylphosphate $0.20 \mu \mathrm{mol}$ and cholesterol 1.5 $\mu$ mol suspended in $1.0 \mathrm{ml}$ of $0.3 \mathrm{M}$ glucose) were added to each well. After a 14-hour incubation, the cells were washed three times with PBS and then fixed by soaking in $10 \%$ formalin. Nuclei and intracellular neutral lipid droplets were then stained with hematoxylin (Sigma Aldrich) and oil red O (Sigma Aldrich), respectively, and the stained cells were observed by light microscopy (Vanox-S model, Olympus).

\section{Assay for $\left[{ }^{14} \mathrm{C}\right]$ Neutral Lipid Synthesis by Macrophages}

Assay for $\left[{ }^{14} \mathrm{C}\right]$ neutral lipid synthesis by mouse macrophages was carried out according to the method described previously [14]. Mouse peritoneal macrophages $\left(5 \times 10^{5}\right.$ cells per $0.25 \mathrm{ml}$ of medium A mentioned above) were cultured in a 48-well plastic microplate (Corning), and then $2.5 \mu \mathrm{l}$ of sample (methanol solution) and $10 \mu \mathrm{l}$ of liposomes together with $5 \mu \mathrm{l}$ of $\left[{ }^{14} \mathrm{C}\right]$ oleic acid ( $1 \mathrm{nmol}$, $1.85 \mathrm{kBq}, 10 \%$ ethanol/PBS solution) were added to each culture. After a 14-hour incubation, the medium was removed, and the cells in each well were washed three times with PBS. The cells were lysed by adding $0.25 \mathrm{ml}$ of PBS containing $0.1 \%(\mathrm{w} / \mathrm{v})$ SDS, and the cellular lipids were extracted and separated on a TLC plate [16]. $\left[{ }^{14} \mathrm{C}\right]$ Cholesteryl ester $\left(\left[{ }^{14} \mathrm{C}\right] \mathrm{CE}\right)$ and $\left[{ }^{14} \mathrm{C}\right]$ triacylglycerol $\left(\left[{ }^{14} \mathrm{C}\right] \mathrm{TG}\right)$ were analyzed with a bio-imaging analyzer (BAS 2000, Fuji Film). 


\section{Other Biological Assays}

Antimicrobial activity against 14 species of microorganisms was tested by the agar diffusion assay using paper disks (i.d. $6 \mathrm{~mm}$, Advantec). Bacteria were grown on Mueller-Hinton agar medium (Difco). Fungi and yeasts were grown on potato broth agar medium. Antimicrobial activity was observed after a 24-hour incubation at $37^{\circ} \mathrm{C}$ for bacteria and after a 48 -hour incubation at $27^{\circ} \mathrm{C}$ for fungi and yeasts.

\section{Results}

\section{Taxonomy of the Producing Fungus}

Colonies on OA were $85 \sim 90 \mathrm{~mm}$ diameter after 14 days at $22^{\circ} \mathrm{C}$, thin floccose, dark covert gray ( $2 \mathrm{ih}$ ) or partially rose ( $71 / 2$ ic) in color. The reverse side was light beige $(3 \mathrm{ec})$ to dark covert gray ( $2 \mathrm{ih}$ ). Colonies on MEA were $85 \sim 90 \mathrm{~mm}$ after 14 days at $22^{\circ} \mathrm{C}$, floccose, pearl ( $3 \mathrm{ba}$ ) to olive gray (1 1/2 ig) or partially light persimmon (5 ic) in color. The reverse was beige ( $3 \mathrm{ge})$ to pearl $(3 \mathrm{ba})$. The pigment was produced in MEA, persimmon (5 lc) to light persimmon ( 5 ic). The dark brown pycnidiax were abundantly formed on both media (Fig. 2A). The pycnidia were semiimmersed, pseudoparenchymatous, thin-walled, globose to subglobose, $150 \sim 350 \mu \mathrm{m}$ in diameter, with single ostiole or multiostiole, and solitary or sometimes aggregated (Fig. 2B). Conidiogenous cells were lining inner of the pycnidium, phialidic, ampulliform to doliiform or difformed (Fig. 2C). A number of slimy conidia were formed abundantly within the pycnida (Fig. 2B). Conidia were single-celled, ellipsoid to oblong-ellipsoid, smoothwalled, pale cream, and $4.0 \sim 6.5 \times 2.3 \sim 3.0 \mu \mathrm{m}$ (average $5.0 \times 2.7 \mu \mathrm{m}$ ) in size (Fig. 2D). Clamydospores were observed, globose to subglobose or ellipsoid to oblongellipsoid, hyaline to brownish in color.

From the above characteristics, strain FKI-1840 was considered to belong to the genus Phoma [11, 17] and named Phoma sp. FKI-1840. The strain was deposited at the National Institute of Bioscience and HumanTechnology, Agency of Industrial Science and Technology Japan, as ABP-10150.

\section{Fermentation}

A slant culture of the strain FKI-1840 grown on LCA (glycerol $0.1 \%, \quad \mathrm{KH}_{2} \mathrm{PO}_{4} \quad 0.08 \%, \mathrm{~K}_{2} \mathrm{HPO}_{4} \quad 0.02 \%$, $\mathrm{MgSO}_{4} \cdot 7 \mathrm{H}_{2} \mathrm{O} 0.02 \%, \mathrm{KCl} 0.02 \%, \mathrm{NaNO}_{3} 0.2 \%$, yeast extract $0.02 \%$, agar $1.5 \%, \mathrm{pH} 6.0$ ) was used to inoculate a $50-\mathrm{ml}$ tube containing $10 \mathrm{ml}$ of the seed medium (glucose $2.0 \%$, polypeptone $0.5 \%, \mathrm{MgSO}_{4} \cdot 7 \mathrm{H}_{2} \mathrm{O} 0.05 \%$, yeast extract $0.2 \%, \mathrm{KH}_{2} \mathrm{PO}_{4} 0.1 \%$, agar $0.1 \%$, pH 6.0 ). The tube

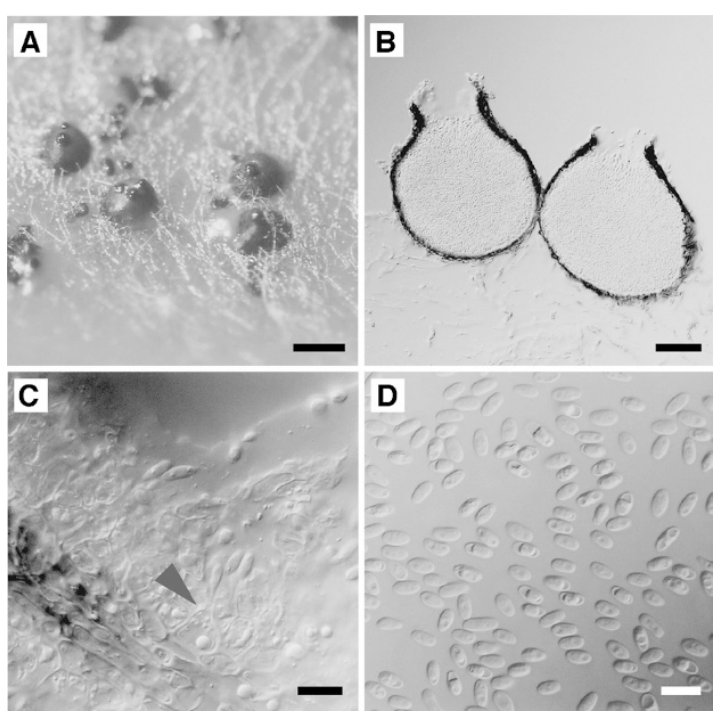

Fig. 2 Photomicrographs of strain FKI-1840. (A) Pycnidia formed on OA. Bar represents $300 \mu \mathrm{m}$. (B) Cross section of pycnidia. Bar represents $50 \mu \mathrm{m}$. (C) Conidiogenous cells (arrowhead). Bar represents $10 \mu \mathrm{m}$. (D) Conidia. Bar represents $10 \mu \mathrm{m}$.

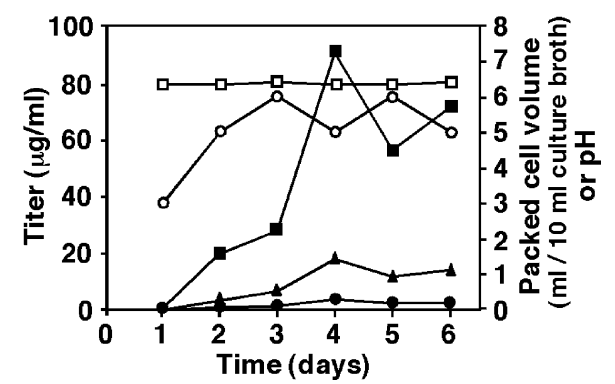

Fig. 3 A typical time course of spylidone production by Phoma sp. FKI-1840. Titer $(\mu \mathrm{g} / \mathrm{ml})$, spylidone (๑), PF1052

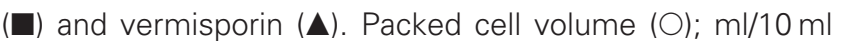
culture broth. $\mathrm{pH}(\square)$.

was shaken on a reciprocal shaker for 2 days at $27^{\circ} \mathrm{C}$. A one-ml portion of the seed culture was then inoculated into a 500-ml Erlenmeyer flask containing $100 \mathrm{ml}$ of the production medium (glycerol $3.0 \%$, oat meal $2.0 \%$, dry yeast $1.0 \%, \mathrm{KH}_{2} \mathrm{PO}_{4} 1.0 \%, \mathrm{Na}_{2} \mathrm{HPO}_{4} 1.0 \%, \mathrm{MgCl}_{2} \cdot 6 \mathrm{H}_{2} \mathrm{O}$ $0.5 \%$ ). The fermentation was carried out at $27^{\circ} \mathrm{C}$. A typical time course of the fermentation is shown in Fig. 3. Spylidone, PF1052 and vermisporin were detected in the culture broth from day 2 to day 3 after inoculation. Their concentrations reached a maximal level $(3.8,91.5$ and $18.1 \mu \mathrm{g} / \mathrm{ml}$, respectively) on day 4 , and then gradually decreased until day 6. 


\section{Isolation}

The 6-day old whole broth (10 liters) was centrifuged at $3000 \mathrm{rpm}$ for 15 minutes. The mycelium was extracted with 5 liters of acetone. After the acetone extracts were filtered and concentrated to remove acetone, the aqueous residue was extracted with ethyl acetate. The extracts were dried over $\mathrm{Na}_{2} \mathrm{SO}_{4}$ and concentrated in vacuo to dryness to yield $5.9 \mathrm{~g}$ of red brown material. The material was dissolved in $\mathrm{CHCl}_{3}$, applied on a silica gel column $(59 \mathrm{~g})$, and eluted stepwise with $100 \% \mathrm{CHCl}_{3}$ and $100: 1,50: 1,10: 1$ and $1: 1(\mathrm{v} / \mathrm{v})$ of $\mathrm{CHCl}_{3}-\mathrm{CH}_{3} \mathrm{OH}$ solvents $[45 \mathrm{ml} \times 4$ fractions (fr.) for each solvent]. Active fractions from the 2 nd fr. of $100: 1$ to the 2 nd fr. of $10: 1$ were concentrated to give a red brown oily material $(4.4 \mathrm{~g})$. The oily material was subjected to a second silica gel column $(44 \mathrm{~g})$. The material was eluted with $3: 1,2: 1,1: 1(\mathrm{v} / \mathrm{v})$ of hexane - EtOAc solvents and $50: 1,10: 1$ and $1: 1(\mathrm{v} / \mathrm{v})$ of $\mathrm{CHCl}_{3}-\mathrm{CH}_{3} \mathrm{OH}$ solvents $(30 \mathrm{ml} \times 5 \mathrm{fr}$. each). Active fractions from the 5 th fr. of $2: 1$ (hexane-EtOAc) to the 4th fr. of $1: 1\left(\mathrm{CHCl}_{3}\right.$ $\left.\mathrm{CH}_{3} \mathrm{OH}\right)$ were collected to give a red brown oil $(454 \mathrm{mg}$ ), which was continuously applied to an ODS column (20 g) and eluted stepwise with $60 \%, 70 \%, 80 \%$ and $90 \% \mathrm{CH}_{3} \mathrm{CN}$ containing $0.05 \%$ trifluoroacetic acid $(10 \mathrm{ml} \times 6$ fr. each $)$. The fractions from the 4th to 6th fr. of $80 \% \mathrm{CH}_{3} \mathrm{CN}$ containing spylidone were concentrated in vacuo to dryness to give a colorless material $(67.8 \mathrm{mg})$. The enriched spylidone was finally purified with preparative HPLC [column; PEGASIL ODS (Senshu Sci. Co.), 4.6×250 mm; solvent, $60 \% \mathrm{CH}_{3} \mathrm{CN}$; detection, $\mathrm{UV}$ at $210 \mathrm{~nm}$; flow rate, $1.0 \mathrm{ml} /$ minute]. Under these conditions, spylidone was eluted as a peak with a retention time of 32.6 minutes (Fig. 4). The collected fraction was concentrated in vacuo to dryness to give pure spylidone $(23.8 \mathrm{mg}$ ) as colorless oil. The fractions from the 1st fr. and 2nd fr. of $90 \% \mathrm{CH}_{3} \mathrm{CN}$ were further purified by HPLC (column; PEGASIL ODS, $20 \times 250 \mathrm{~mm}$; solvent, $80 \% \mathrm{CH}_{3} \mathrm{CN}$ containing $0.05 \%$ trifluoroacetic acid, UV at $210 \mathrm{~nm}$; flow rate, $6 \mathrm{ml} / \mathrm{minute}$ ) to yield pure vermisporin $(3.9 \mathrm{mg})$ as colorless oil. The fractions from the 1st to the 4th fr. of $2: 1$ (hexane - EtOAc) were collected to give a red brown oil $(2.0 \mathrm{~g})$, which was further applied to an ODS column $(80 \mathrm{~g})$ and eluted stepwise with $80 \%, 90 \%$ and $100 \% \mathrm{CH}_{3} \mathrm{CN}$ containing $0.05 \%$ trifluoroacetic acid $(30 \mathrm{ml} \times 10 \mathrm{fr}$. each). From the 10th fr. of $80 \% \mathrm{CH}_{3} \mathrm{CN}$ to the 4 th fr. of $90 \% \mathrm{CH}_{3} \mathrm{CN}$, PF1052 (987 mg) was obtained as colorless oil.

\section{Structure Elucidation of Spylidone}

The physico-chemical properties of spylidone and PF1052 are summarized in Table 1. The data of PF1052, which are comparable to those previously reported [9], are also shown for comparative purpose.

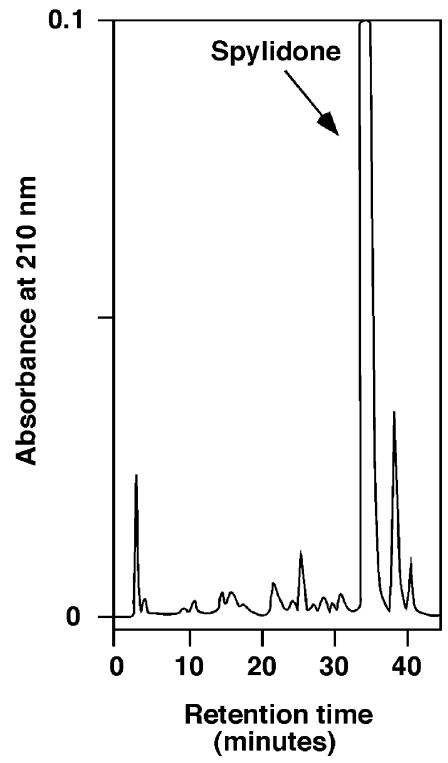

Fig. 4 A chromatographic profile of spylidone purification by preparative HPLC. Column, PEGASIL ODS $4.6 \times 250 \mathrm{~mm}$; solvent $60 \%$ aq acetonitrile; detection, UV at $210 \mathrm{~nm}$; flow rate, $1.0 \mathrm{ml} / \mathrm{minute}$; sample, $0.5 \mathrm{mg}$ of active materials (obtained through ODS column chromatography) dissolved in $5 \mu$ methanol was injected.

Table 1 Physico-chemical properties of spylidone and PF1052

\begin{tabular}{lll}
\hline & \multicolumn{1}{c}{ Spylidone } & \multicolumn{1}{c}{ PF1052 } \\
\hline Appearance & Colorless oil & Colorless oil \\
Molecular weight & 429 & 429 \\
Molecular formula & $\mathrm{C}_{26} \mathrm{H}_{39} \mathrm{NO}_{4}$ & $\mathrm{C}_{26} \mathrm{H}_{39} \mathrm{NO}_{4}$ \\
HRFAB-MS $(\mathrm{m} / z)$ & & \\
$\quad$ Found: & $430.2964(\mathrm{M}+\mathrm{H})^{+}$ & $430.2949(\mathrm{M}+\mathrm{H})^{+}$ \\
Calcd: & 430.2957 & 430.2957 \\
UV $(\mathrm{MeOH})$ & $203(17296)$ & $226(7536)$, \\
$\quad$ & & $291(13691)$ \\
$\lambda_{\max } \mathrm{nm}(\lambda)$ & $+5.6^{\circ}$ & $+38.4^{\circ}$ \\
& $(c=0.1, \mathrm{MeOH})$ & $(c=0.1, \mathrm{MeOH})$ \\
IR $(\mathrm{KBr}) v_{\max }\left(\mathrm{cm}^{-1}\right)$ & $1767,1718,1685$, & $1701,1647,1608$, \\
& $1460,1392,1240$ & $1456,1387,1335$ \\
\hline
\end{tabular}

The molecular formula of spylidone was determined to be $\mathrm{C}_{26} \mathrm{H}_{39} \mathrm{NO}_{4}$ on the basis of HRFAB-MS measurement ( $m / z$, found 430.2964, calcd 430.2957 for $\mathrm{C}_{26} \mathrm{H}_{40} \mathrm{NO}_{4}$ $\left.[\mathrm{M}+\mathrm{H}]^{+}\right)$. The IR spectrum suggested the presence of three carbonyl groups $\left(1767,1718\right.$ and $\left.1685 \mathrm{~cm}^{-1}\right)$. The ${ }^{13} \mathrm{C}$ NMR spectrum (in $\mathrm{CDCl}_{3}$ ) showed 26 resolved peaks, which were classified into seven methyl carbons, three methylene carbons, nine methine carbons, two $s p^{2}$ methine 
Table $2{ }^{1} \mathrm{H}$ and ${ }^{13} \mathrm{C}$ NMR chemical shifts of spylidone and PF1052.

\begin{tabular}{|c|c|c|c|c|}
\hline \multirow{2}{*}{ Position } & \multicolumn{2}{|r|}{ Spylidone } & \multicolumn{2}{|r|}{ PF1052 } \\
\hline & $\delta_{\mathrm{C}}$ & $\delta_{\mathrm{H}}$ & $\delta_{\mathrm{C}}$ & $\delta_{\mathrm{H}}$ \\
\hline 1 & $200.5 \mathrm{~s}$ & - & $190.2 \mathrm{~s}$ & - \\
\hline 2 & $39.6 \mathrm{~d}$ & $3.34 \mathrm{dd}(J=12.0,12.0 \mathrm{~Hz})$ & $35.2 \mathrm{~d}$ & $4.23 \mathrm{dd}(J=11.0,11.0 \mathrm{~Hz})$ \\
\hline 3 & $33.3 \mathrm{~d}$ & $2.25 \mathrm{ddd}(J=12.0,4.5,4.5 \mathrm{~Hz})$ & $41.9 \mathrm{~d}$ & $2.20 \mathrm{ddd}(J=11.0,4.5,3.0 \mathrm{~Hz})$ \\
\hline 4 & $36.7 \mathrm{~d}$ & $1.81 \mathrm{~m}$ & $33.3 d$ & $1.46 \mathrm{~m}$ \\
\hline 5 & $38.6 t$ & $0.97 \mathrm{~m}^{\mathrm{a}}, 1.34 \mathrm{~m}$ & $37.9 t$ & $1.06 \mathrm{~m}, 1.66 \mathrm{~m}^{\mathrm{a}}$ \\
\hline 6 & $33.1 \mathrm{~d}$ & $1.44 \mathrm{~m}$ & $37.9 d$ & $1.72 \mathrm{~m}$ \\
\hline 7 & $39.9 t$ & $0.77 \mathrm{~m}^{\mathrm{a}}, 1.65 \mathrm{~m}$ & $37.7 t$ & $1.06 \mathrm{~m}, 1.66 \mathrm{~m}^{\mathrm{a}}$ \\
\hline 8 & $37.7 d$ & $2.12 \mathrm{~m}$ & $39.9 d$ & $2.08 \mathrm{~m}$ \\
\hline 9 & $138.0 \mathrm{~d}$ & $6.1 \mathrm{ddd}(J=10.0,6.0,2.5 \mathrm{~Hz})$ & $133.8 \mathrm{~d}$ & $5.80 \mathrm{ddd}(J=10.0,6.0,2.5 \mathrm{~Hz})$ \\
\hline 10 & $119.6 \mathrm{~d}$ & $5.57 \mathrm{dd}(J=10.0,3.0 \mathrm{~Hz})$ & $125.2 \mathrm{~d}$ & $5.33 \mathrm{ddd}(J=10.0,2.0,1.0 \mathrm{~Hz})$ \\
\hline 11 & $47.8 d$ & $2.43 \mathrm{ddd}(J=12.0,3.0,2.5 \mathrm{~Hz})$ & $51.5 d$ & $2.40 \mathrm{ddd}(J=11.0,2.5,1.0 \mathrm{~Hz})$ \\
\hline 12 & $74.2 \mathrm{~s}$ & - & $63.0 \mathrm{~s}$ & - \\
\hline $12-\mathrm{OH}$ & - & $3.49 \mathrm{~s}, \mathrm{br}$ & - & - \\
\hline 13 & $46.9 \mathrm{~d}$ & $2.97 \mathrm{q}(J=7.0 \mathrm{~Hz})$ & $58.7 \mathrm{~d}$ & $2.80 \mathrm{q}(J=5.5 \mathrm{~Hz})$ \\
\hline 14 & $21.8 \mathrm{q}$ & $0.73 \mathrm{~d}(J=7.0 \mathrm{~Hz})$ & $14.0 \mathrm{q}$ & $1.24 \mathrm{~d}(J=5.5 \mathrm{~Hz})$ \\
\hline 15 & $22.2 \mathrm{q}$ & $0.89 \mathrm{~d}(J=6.5 \mathrm{~Hz})$ & $22.3 \mathrm{q}$ & $0.96 \mathrm{~d}(J=7.0 \mathrm{~Hz})$ \\
\hline 16 & $23.2 \mathrm{q}$ & $1.41 \mathrm{~s}$ & $20.4 \mathrm{q}$ & $0.89 \mathrm{~d}(J=7.0 \mathrm{~Hz})$ \\
\hline 17 & $11.1 \mathrm{q}$ & $0.92 \mathrm{~d}(J=7.0 \mathrm{~Hz})$ & $12.2 \mathrm{q}$ & $1.16 \mathrm{~s}$ \\
\hline $1^{\prime}$ & $169.8 \mathrm{~s}$ & - & $173.6 \mathrm{~s}$ & - \\
\hline $2^{\prime}$ & $72.5 \mathrm{~s}$ & - & $103.9 \mathrm{~s}$ & - \\
\hline $3^{\prime}$ & $206.5 \mathrm{~s}$ & - & $194.1 \mathrm{~s}$ & - \\
\hline $4^{\prime}$ & $72.2 \mathrm{~d}$ & $3.71 \mathrm{~d}(J=3.0 \mathrm{~Hz})$ & $69.9 \mathrm{~d}$ & $3.66 \mathrm{~d}(J=3.0 \mathrm{~Hz})$ \\
\hline $5^{\prime}$ & $35.6 \mathrm{~d}$ & $1.92 \mathrm{~m}$ & $35.8 d$ & $1.94 \mathrm{~m}$ \\
\hline $6^{\prime}$ & $25.9 t$ & $1.50 \sim 1.62 \mathrm{~m}^{\mathrm{a}}$ & $25.2 \mathrm{t}$ & $1.50 \sim 1.62 \mathrm{~m}^{\mathrm{a}}$ \\
\hline $7^{\prime}$ & $12.3 q$ & $0.96 \mathrm{t}(\mathrm{J}=7.0 \mathrm{~Hz})$ & $12.4 \mathrm{q}$ & $0.98 \mathrm{t}(J=7.0 \mathrm{~Hz})$ \\
\hline $8^{\prime}$ & $27.5 \mathrm{q}$ & $3.01 \mathrm{~s}$ & $26.7 q$ & $2.93 \mathrm{~s}$ \\
\hline $9^{\prime}$ & $14.3 \mathrm{q}$ & $0.86 \mathrm{~d}(J=7.0 \mathrm{~Hz})$ & $14.0 \mathrm{q}$ & $0.82 \mathrm{~d}(J=7.0 \mathrm{~Hz})$ \\
\hline
\end{tabular}

${ }^{a}$ Overlapping signals.

carbons, two $s p^{3}$ quaternary carbons, one of which was an oxygenated quaternary carbon, and three carbonyl carbons by analysis of the DEPT spectra. The ${ }^{1} \mathrm{H}$ NMR spectrum (in $\mathrm{CDCl}_{3}$ ) displayed 39 proton signals, four of which were assigned to an $\mathrm{OH}$ proton $(\delta 3.49)$ and an $\mathrm{NCH}_{3}$ proton $(\delta$ 3.01). These results supported the molecular formula. The connectivity of proton and carbon atoms was established by the ${ }^{13} \mathrm{C}-{ }^{1} \mathrm{H}$ HMQC spectrum (Table 2). The analyses of the ${ }^{1} \mathrm{H}-{ }^{1} \mathrm{H}$ COSY and spin decoupling revealed the presence of three partial structures I to III as shown in Fig. 5. Furthermore, ${ }^{13} \mathrm{C}-{ }^{1} \mathrm{H}$ long range couplings of ${ }^{2} J$ and ${ }^{3} J$ were measured in the ${ }^{13} \mathrm{C}^{-1} \mathrm{H}$ HMBC spectrum (Fig. 6). First, the following evidence regarding the southern part containing the partial structure I became clear. 1) The cross peaks from 2-CH $(\delta 3.34)$ and 3-CH $(\delta 2.25)$ to $\mathrm{C}-1$ ( $\delta$ 200.5) showed the presence of the carbonyl carbon oriented adjacent to the partial structure I. 2) The cross peaks from
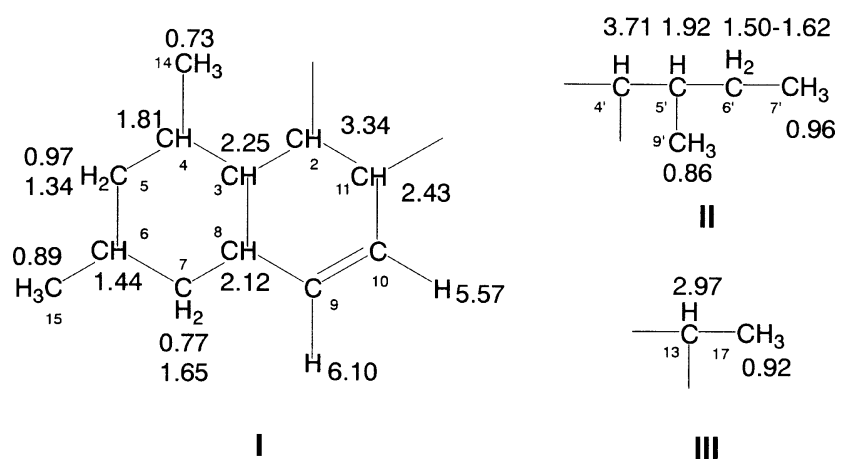

Fig. 5 Partial structures of spylidone.

$16-\mathrm{CH}_{3}(\delta 1.41)$ to $\mathrm{C}-11(\delta 47.8$ and $\mathrm{C}-12(\delta 74.2$, and from $11-\mathrm{CH}(\delta 2.43)$ to $\mathrm{C}-12$ showed that $16-\mathrm{CH}_{3}$ was connected to the $\mathrm{C}-12$ oxygenated quaternary carbon, 


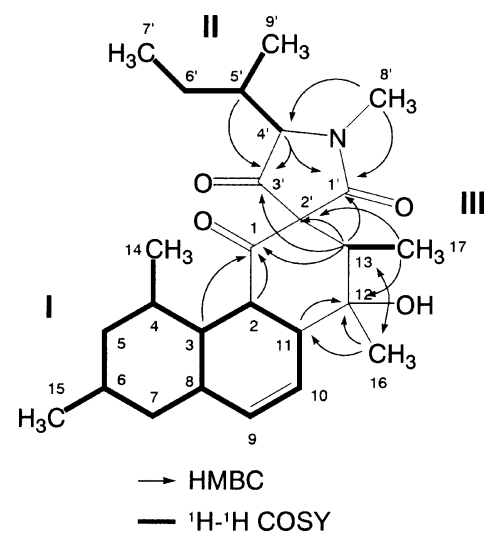

Fig. $6{ }^{1} \mathrm{H}_{-}{ }^{1} \mathrm{H}$ COSY, ${ }^{13} \mathrm{C}-{ }^{-1} \mathrm{H} \quad \mathrm{HMOC}$ and ${ }^{13} \mathrm{C}^{-1} \mathrm{H} \mathrm{HMBC}$ experiments of spylidone.

which was attached to $\mathrm{C}-11$ in the partial structure I. 3) The cross peaks from $17-\mathrm{CH}_{3}(\delta 0.92)$ to $\mathrm{C}-12$, and from 13 $\mathrm{CH}\left(\delta\right.$ 2.97) to $\mathrm{C}-16\left(\begin{array}{l}\delta \\ \delta\end{array} 23.2\right)$ showed that $\mathrm{C}-12$ was attached to the partial structure III. 4) The cross peaks from $13-\mathrm{CH}$ to $\mathrm{C}-1$ and $\mathrm{C}-2^{\prime}(\delta 72.5)$, and from $17-\mathrm{CH}_{3}$ to $\mathrm{C}-2^{\prime}$ showed that a six membered ring was formed with $\mathrm{C}-1, \mathrm{C}-$ 2, C-11, C-12, C-13 and C-2' as shown in Fig. 6, resulting in formation of a tricyclic structure containing the partial structure I. Second, the following evidence regarding the northern part containing the partial structure II became clear. 1) The cross peaks from $4^{\prime}-\mathrm{CH}(\delta 3.71)$ to $\mathrm{C}-3^{\prime}(\delta$ $206.5)$, and from $5^{\prime}-\mathrm{CH}(\delta 1.92)$ to $\mathrm{C}-3^{\prime}$ showed that the $\mathrm{C}$ $3^{\prime}$ carbonyl carbon was attached to the partial structure II. 2) The cross peak from $\mathrm{NCH}_{3}$ to $\mathrm{C}-4$ ' ( $\delta$ 72.2) showed that the $\mathrm{NCH}_{3}$ group was attached to the partial structure III. This result was also supported by the chemical shift of C-4' ( $\delta$ 72.2). Third, the connection between the southern part and the northern part mentioned above was established as follows; 1$)$ The cross peaks from $\mathrm{NCH}_{3}$ to $\mathrm{C}-1^{\prime}(\delta$ 169.8) showed that $\mathrm{NCH}_{3}$ was connected to the C-1' carboyl carbon. 2) The cross peaks from $13-\mathrm{CH}$ to $\mathrm{C}-1^{\prime}, \mathrm{C}-2^{\prime}$ and $\mathrm{C}-3^{\prime}$ showed that the $\mathrm{C}-1^{\prime}$ and $\mathrm{C}-3^{\prime}$ carbonyl carbons were attached to the six membered ring. Taking the degree of unsaturation into consideration, a five membered heterocyclic spiro ring should be formed as shown in Fig. 6 . The chemical shift of C-2' $(\delta 72.5)$ was comparable with that of a spiro quaternary carbon [18]. Taken together, the planar structure of spylidone was elucidated as shown in Fig. 1. These chemical shifts of spylidone were consisted with that of PF1052 at partial structures I and II and C-8'.

The relative stereochemistry of the tricyclic part (A-B-C) was examined (Fig. 7). The small coupling constants $\left(J_{3-\mathrm{CH}, 8-\mathrm{CH}}=4.5 \mathrm{~Hz}\right)$ in ${ }^{1} \mathrm{H}$ NMR indicated the cis configuration between the $\mathrm{A}$ and $\mathrm{B}$ rings, which was also supported by NOEs between $3-\mathrm{CH}$ and $8-\mathrm{CH}$. The large

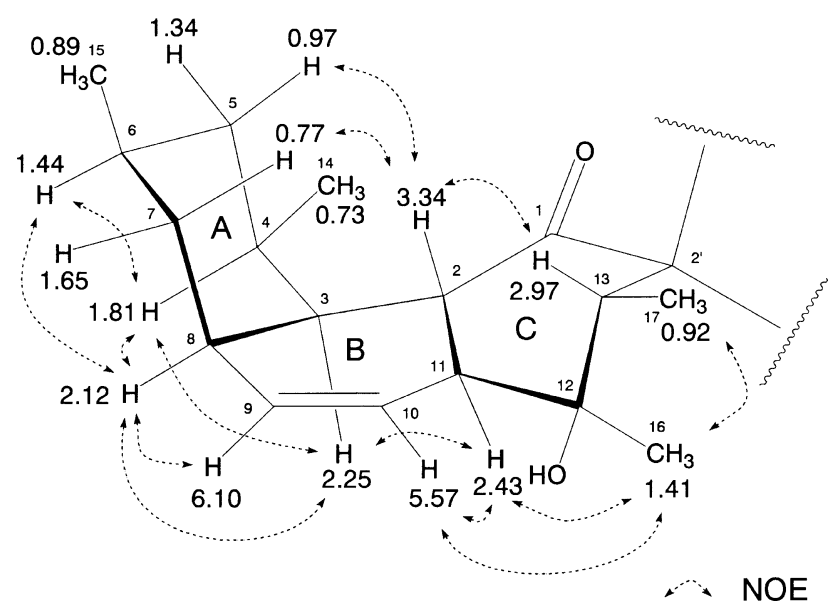

Fig. 7 NOE experiments of spylidone.

coupling constants $\left(J_{2-\mathrm{CH}, 3-\mathrm{CH}}=J_{2-\mathrm{CH}, 11-\mathrm{CH}}=12 \mathrm{~Hz}\right)$ indicated the trans configuration between the $\mathrm{B}$ and $\mathrm{C}$ rings, which was also supported by NOEs between 3-CH and 11-CH. From these results, it was revealed that the $\mathrm{B}$ ring formed a conformation as shown in Fig. 7. Furthermore, observations of NOEs between 4-CH and 3-CH/6-CH/8$\mathrm{CH}$, between 6-CH and 8-CH and between 2-CH and 5$\mathrm{CH} / 7-\mathrm{CH}$ indicated that the A ring formed a chairconformation. Similarly, NOE observation between 2-CH and $13-\mathrm{CH}$, between $16-\mathrm{CH} 3$ and $10-\mathrm{CH} / 11-\mathrm{CH} / 17-\mathrm{CH}_{3}$ indicated that the $\mathrm{C}$ ring formed a boat-conformation. Taken together, the relative stereochemistry of the tricyclic part was determined as shown in Fig. 1.

\section{Biological Properties \\ Inhibition of Lipid Droplet Accumulation in Macrophages}

In the control assay (no drug), mouse peritoneal macrophages accumulated a massive amount of lipid droplets in the cytosol. In the presence of spylidone at $10 \sim 50 \mu \mathrm{M}$, the size and number of lipid droplets in the macrophages obviously reduced in a dose-dependent manner (data not shown). No morphological changes or cytotoxic effects were observed on macrophages even at the highest dose $(186 \mu \mathrm{M})$, indicating that spylidone specifically inhibits lipid droplet accumulation in macrophages. On the other hand, PF1052 and vermisporin caused a reduction of lipid droplets but weak cytotoxic effects with morphological damage to macrophages (data not shown).

\section{Inhibition of CE Synthesis in Macrophages}

In the control assay (no drug), about $40 \%$ of exogenously added $\left[{ }^{14} \mathrm{C}\right]$ oleic acid was incorporated into the neutral 


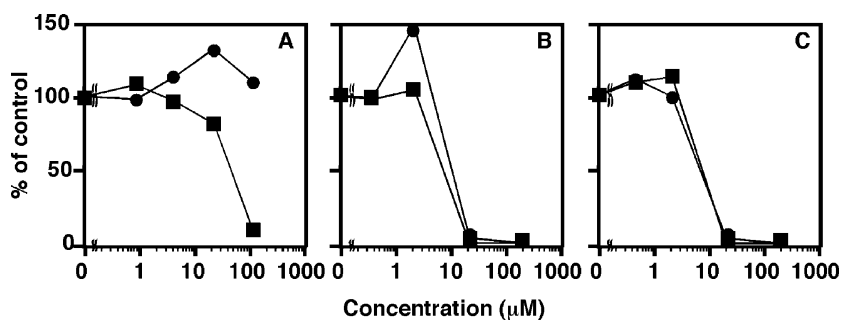

Fig. 8 Effect of spylidone, PF1052 and vermisporin on $\left[{ }^{14} \mathrm{C}\right]$ neutral lipid synthesis from $\left[{ }^{14} \mathrm{C}\right]$ oleic acid by macrophages. Macrophage monolayers obtained from $5 \times 10^{5}$ cells per well in a microplate were incubated in $0.25 \mathrm{ml}$ of medium with a phospholipid/cholesterol liposome composed of phosphatidylcholine, phosphatidylserine, dicetylphosphate, and cholesterol at a molar ratio $10: 10: 2: 15$ and $\left[{ }^{14} \mathrm{C}\right.$ ]oleic acid in the absence or presence of the indicated amounts of spylidone (A), PF1052 (B) or vermisporin (C). After a 14-hour incubation, cholesteryl $\left[{ }^{14} \mathrm{C}\right.$ ]oleate $(\boldsymbol{\square})$ and $\left[{ }^{14} \mathrm{C}\right] \mathrm{TG}(\mathbf{O})$ were separated on TLC, determined with a radioscanner as described in the "materials and methods". The results are plotted as percent of control (without a drug).

lipids, $\left[{ }^{14} \mathrm{C}\right] \mathrm{CE}$ (about 25\%) and $\left[{ }^{14} \mathrm{C}\right] \mathrm{TG}$ (about 5\%), which are the main constituents of lipid droplets in macrophages [13]. As shown in Fig. 8, spylidone inhibited $\left[{ }^{14} \mathrm{C}\right] \mathrm{CE}$ synthesis in a dose-dependent manner with an $\mathrm{IC}_{50}$ value of $42 \mu \mathrm{M}$, but showed almost no inhibition of $\left[{ }^{14} \mathrm{C}\right] \mathrm{TG}$ synthesis even at the highest dose $(109 \mu \mathrm{M})$, indicating that spylidone selectively inhibits CE synthesis in macrophages. On the other hand, PF1052 and vermisporin inhibited $\left[{ }^{14} \mathrm{C}\right] \mathrm{CE}, \quad\left[{ }^{14} \mathrm{C}\right] \mathrm{TG}$ and $\left[{ }^{14} \mathrm{C}\right]$ phospholipid synthesis, probably due to their weak cytotoxic effects on macrophages. Thus, among the three compounds, only spylidone selectively inhibits CE synthesis in macrophages. These data support the results of the lipid droplet accumulation in macrophages as described above.

\section{Other Biological Activities}

No antimicrobial activity of spylidone was observed at a concentration of $10 \mu \mathrm{g} /$ disk $(2.3 \mathrm{mM})$ against the following microorganisms; Bacillus subtilis PCI 219, Staphylococcus aureus FDA 209P, Micrococcus luteus PCI 1001, Escherichia coli NIHJ, Escherichia coli NIHJJ-2 IFO 12734, Pseudomonas aeruginosa P-3, Xanthomonas campestris pv. oryzae, Bacteroides fragilis ATCC 23745, Acholeplasma laidlawii PG8, Pyricularia oryzae KF 180, Aspergillus niger ATCC6275, Mucor racemosus IFO4581, Candida albicans and Saccharomyces cerevisiae. On the other hand, PF1052 showed antimicrobial activities against<smiles>[R]C1NC(=O)C2(C(=O)C1=O)C(/C=C/C=C/C(C)C(O)CC)CC1C=CC3CC(C)CC(C)C3C12C</smiles>

$$
\begin{aligned}
& \text { Delaminomycin A2: } \mathrm{R}=\mathrm{OH} \\
& \text { Delaminomycin B2: } \mathrm{R}=\mathrm{OCH}_{3}
\end{aligned}
$$$$
\text { Delaminomycin } \mathrm{C} 2: \mathrm{R}=\mathrm{H}
$$

Fig. 9 Structures of delaminomycin derivatives.

B. subtilis, $S$. aureus, $M$. luteus, $X$. campestris, $B$. fragilis, $P$. oryzae and C. albicans, with inhibition zones of 10, 10, 13, $11,12,15$ and $12 \mathrm{~mm}$ at $10 \mu \mathrm{g} /$ disk, respectively.

\section{Discussion}

The known antibiotics, PF1052 and vermisporin structurally related to spylidone were originally produced by different fungi Phoma sp. [9] and Ophiobolus vermisporus [10], respectively. However, Phoma sp. FKI1840 was found to produce all three compounds as described in this paper although the metabolites produced by the other fungi hadn't been analyzed in detail. A similar spiro ring structure to that in spylidone containing a 2,4pyrrolidinedione moiety was reported for derivatives (Fig. 9) of delaminomycin, an extracellular matrix receptor antagonist produced by Streptomyces albulus [18]. The derivatives were reported to be produced by the treatment of delaminomycin with $\mathrm{HCl}-\mathrm{MeOH}$. Therefore, it had been suspected that spylidone is produced by the acid treatment of PF1052 or unknown metabolites. However, no products were obtained by the treatment of PF1052, and no increase in the production of spylidone was observed by the treatment of the culture extracts of Phoma sp. FKI-1840. Therefore, we concluded that spylidone was a metabolite of the fungus.

The absolute stereochemistry of vermisporin was demonstrated as shown in Fig. 1 [19]. In view of the common biosynthetic origin of these compounds, we presume that PF1052 shares the same stereochemistry of vermisporin and that spylidone does except for C-12, C-13 and $\mathrm{C}-2{ }^{\prime}$. As expected, the $\mathrm{A}$ and $\mathrm{B}$ rings of spylidone were shown to be the same as that of vermisporin from NOE experiments. Further experiments are needed to define the stereochemistry of C-2', C-4' and C-5'.

Among the three compounds produced by Phoma sp. FKI-1840, only spylidone showed the activity of inhibiting 
lipid droplet accumulation in macrophages. The others showed a weak cytotoxic effect on macrophages, and were reported to show antimicrobial activity $[9,10]$, whereas spylidone showed no antimicrobial activity. Thus, it is plausible that the spiro ring in spylidone is responsible for selective inhibition of lipid droplet formation in macrophages. Furthermore, spylidone inhibited CE synthesis, but didn't inhibit TG synthesis. The inhibition site of spylidone on CE synthesis in macrophages remains to be investigated.

Acknowledgments This study was supported in part by the grant of Kakenhi 16073215, Ministry of Education, Culture, Sports, Science and Technology, Japan \& the 21st Century COE Program. We express our thanks to Ms N. Sato for NMR experiments, Ms T. Sakabe and Ms A. Nakagawa for mass spectra.

\section{References}

1. Goldstein JL, Ho YK, Basu SK, Brown MS. Binding site on macrophages that mediates uptake and degradation of acetylated low density lipoprotein, producing massive cholesterol deposition. Proc Natl Acad Sci USA 76: 333337 (1979)

2. Brown MS, Goldstein JL, Krieger M, HO YK, Anderson RGW. Reversible accumulation of cholesteryl esters in macrophages incubated with acetylated lipoproteins. J Cell Biol 82: 597-613 (1979)

3. Scaffner T, Taylor K, Bartucci EJ, Fisher-Dzoga KF, Beeson JH, Glagov S, Wisser RW. Arterial foam cells with distinctive immunomorphological and histochemical features of macrophages. Am J Pathol 100: 57-73 (1980)

4. Gerrtiy RG. The role of the monocyte in atherogenesis. I. Transition of blood-borne monocytes into foam cells in fatty lesions. Am J Pathol 103: 181-190 (1981)

5. Namatame I, Tomoda H, Si S, Yamaguchi Y, Masuma R, Ōmura, S. Beauveriolides, specific inhibitors of lipid droplet formation in mouse macrophages, produced by Beauveria sp. FO-6979. J Antibiot 52: 1-6 (1999)

6. Namatame I, Tomoda H, Ishibashi S, Ōmura S. Antiatherogenic activity of fungal beauveriolides, inhibitors of lipid droplet accumulation in macrophages. Proc Natl Acad Sci USA 101: 737-742 (2004)

7. Tomoda H, Namatame I, Si S, Kawaguchi K, Masuma R, Namikoshi M, Ōmura S. Phenochalasins, inhibitors of lipid droplet formation in mouse macrophages, produced by Phomopsis sp. FT-0211. J Antibiot 52: 851-856 (1999)

8. Namatame I, Tomoda H, Matsuda D, Tabata N, Kobayashi S, Ōmura S. K97-0239A and B, new inhibitors of macrophage foam cell formation, produced by Streptomyces sp. K970239. Proc Japan Acad. 78B: 45-50 (2002)

9. Takahashi A, Igarashi M, Tamamura T, Tezuka Y, Sato S, Kutsuma S, Arita K, Osanawa H, Takeuchi T. Preparation of antibiotic PF 1052 derivatives as agricultural and horticultural fungicides. Jpn Kokai Tokkyo Koho JP 08059612 (1996)

10. Mikawa T, Chiba N, Ogishi H, Sato Y, Miyaji S, Sezaki M. Antimicrobial formulations containing vermisporin. Jpn Kokai Tokkyo Koho JP 02040328 (1990)

11. Boerema GH, Gruyter JDe, Noordeloos ME, Hamers MEC. Phoma Identification Manual, CABI Publishing (2004)

12. Taylor HD, Knoche L, Granville WC, Color Harmony Manual 4th Ed., Container of America, Chicago (1958)

13. Yamaguchi Y, Masuma R, Uchida R, Arai M, Tomoda H, Ömura S. Phoma sp. FOM-8108, a producer of gentisylquinones, isolated from sea sand. Mycoscience 43: 127-133 (2002)

14. Namatame I, Tomoda H, Arai H, Inoue K, Ōmura S. Complete inhibition of mouse macrophage-derived foam cell formation by triacsin C. J Biochem 125: 319-327 (1999)

15. Goldstein JL, Basu SK, Brown MS. Receptor-mediated endocytosis of low-density lipoprotein in cultured cells. Methods Enzymol 98: 241-260 (1983)

16. Bligh EG, Dyer W. A rapid method of total lipid extraction and purification. Can J Biochem Physiol 37: 911-917 (1959)

17. Domsch KH, Gams W, Anderson TH. Compendium of Soil Fungi. Vol. 1. pp. 630-643, IHW-Verlag (1993)

18. Ueno M, Someno T, Sawa R, Iinuma H, Naganawa $H$, Ishizuka M, Takeuchi T. Delaminomycins, novel nonpeptide extracellular matrix receptor antagonist and a new class of potent immunomodulator. J Antibiot 46: 979-984 (1993)

19. Minowa N, Kodama Y, Hariyama K, Mikawa T. A degradation study of vermisporin and determination of its absolute configuration. Heterocycles 48: 1639-1642 (1998) 